\title{
「構造化シナリオ手法」に関する実践事例報告 ーアーゴデザイン部会合宿研究会のワークショップ成果を中心にー
} ○早川誠二(侏リコー)、上田義弘（富士通(株)、高橋克実（ホロンクリエイト(侏)， 郷 健太郎 (山梨大学)、柳田宏治 (倉敷芸術科学大学)、山崎和彦 (千葉工業大学)

Structured Scenarios in the Ubiquitous Design Methodology

Seiji Hayakawa(Ricoh Company, Ltd.), Yoshihiro Ueda(Fujitsu, Ltd.),Katsumi Takahashi(Holon Create Inc.), Kentaro Go(University of Yamanashi),Koji Yanagida(Kurashiki University of Science and the Arts),

Kazuhiko Yamazaki(Chiba Institute of Technology)

\section{1.はじめに}

日本人間工学会アーゴデザイン部会では、ュ ビキタス時代のデザイン方法論である「構造化 シナリオ手法」に関して、ワークショップを実 施した。ここでは、ワークショップの概要とそ こで得られた知見に関して紹介する。

\section{2. ワークショップの概要}

\section{1. ワークショップのテーマとの目標}

今回のワークショップでは、交通系 IC カー ドを題材として、交通機関利用以外の新しいサ 一ビスを開発することをテーマとした。前提と して、参加者（約 50 名）に対し、東日本旅客 鉄道(株)IT・Suica 事業本部の椎橋章夫氏に、 Suica の開発の歴史、現状のサービス、今後の 展開に関する講演を実施した。

また、参加者の目標としては、昨年実施した ペルソナ手法の実践に続くステップとして、構 造化シナリオ手法を理解し、各シナリオを描く ことと、手法の評価及び改善提案においた。

\section{2. ワークショップの進め方}

ワークショップでは、まず構造化シナリオ手 法の概要を説明し、サービス、アクティビティ、 インタラクションの各シナリオの記述方法と その評価方法に関して概要を説明した。実際の ワークショップは、各 10 人程度の 5 つのグル ープに分かれた作業を行った。

くワークショップ 1 >

ワークショップでは、テーマに沿って新たなサー ビスを自由に発想し、サービスシナリオを記述する とともに、いくつか抽出されたシナリオを評価し、有 カなサービス一つを選定した。

選定されたサービスシナリオに対し、ペルソ ナを想定したアクティビティシナリオを記述 した。ペルソナは、あらかじめ用意した 4 人の

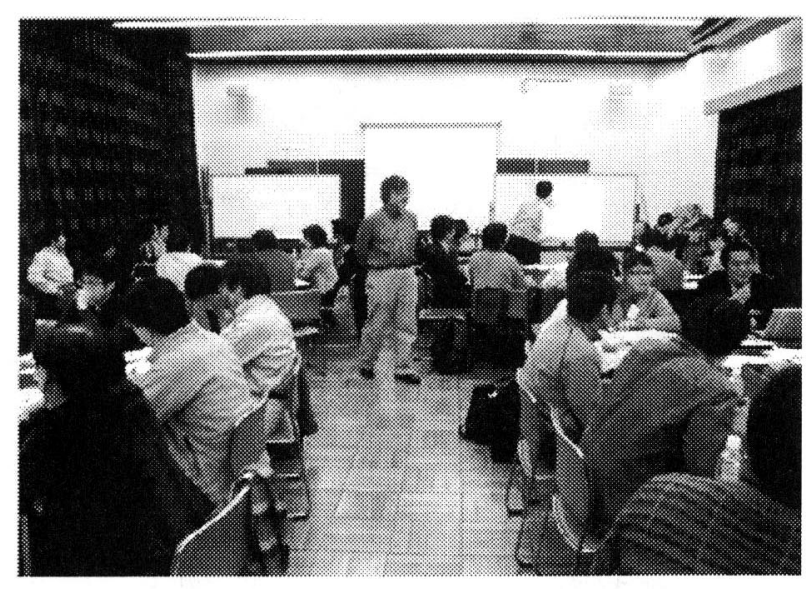

ペルソナの中から任意に 2 人を選んで用いた。 <ワークショップ2>

記述されたアクティビティシナリオを評価 し、絞り込まれたシナリオの中から一部のタス クを抽出し、そのタスクに関するインタラクシ ヨンシナリオを記述した。

くワークショップ $3>$

全体のシナリオの整合を取るとともに、実際 の構造化シナリオ手法を用いて新たなサービ スを創出する作業（シナリオ記述による展開方 法）における課題を検討した。

3. ワークショップの成果

ワークショップ実施の結果、5つのグループ から構造化シナリオ手法の実践結果として、サ 一ビスシナリオ、アクティビティシナリオ、イ ンタラクションシナリオ及び手法に関する評 価と改善要望や感想が得られた。

実際のワークショップでは、各シナリオを記 述する際に各シナリオ間を行きつ戻りつし、そ の記述精度を上げていることがわかった。

また、最後のプレゼンテーションにおいて、 参加者が相互にアウトプットの評価も実施し

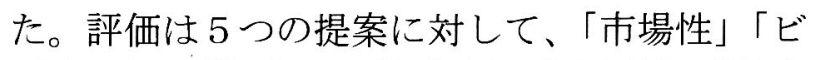
ジネス性」「社会性」「新規性」「有用性」「魅力 
性」「実現性」の観点から行った。この評価結 果を参考にアウトプットの一例を図 1 に示す。 4. 構造化シナリオ手法に対する評価

今回のワークショップでは、シナリオ作成を 実体験すると同時に、構造化シナリオ手法の有 効性を参加者に評価していただいた。同時に各 グループがシナリオ作成を実践する過程を通 してツール類の使用性や改善ポイント等に関
する意見を頂いた。その結果、手法としての有 効性に関しては参加者の多くの皆さんから評 価していただいたと考えられる。また、使用性 に関しては、記入サンプルの必要性や、ワーク シートの改善提案等、様々なアイデアを頂いた。 今後は開発現場で実際に活用できる手法にす るべく、皆さんから頂いたアイデアをべースに 改善を進めたい。

図 1 構造化シナリオ手法で作成した 3 階層のシナリオ事例
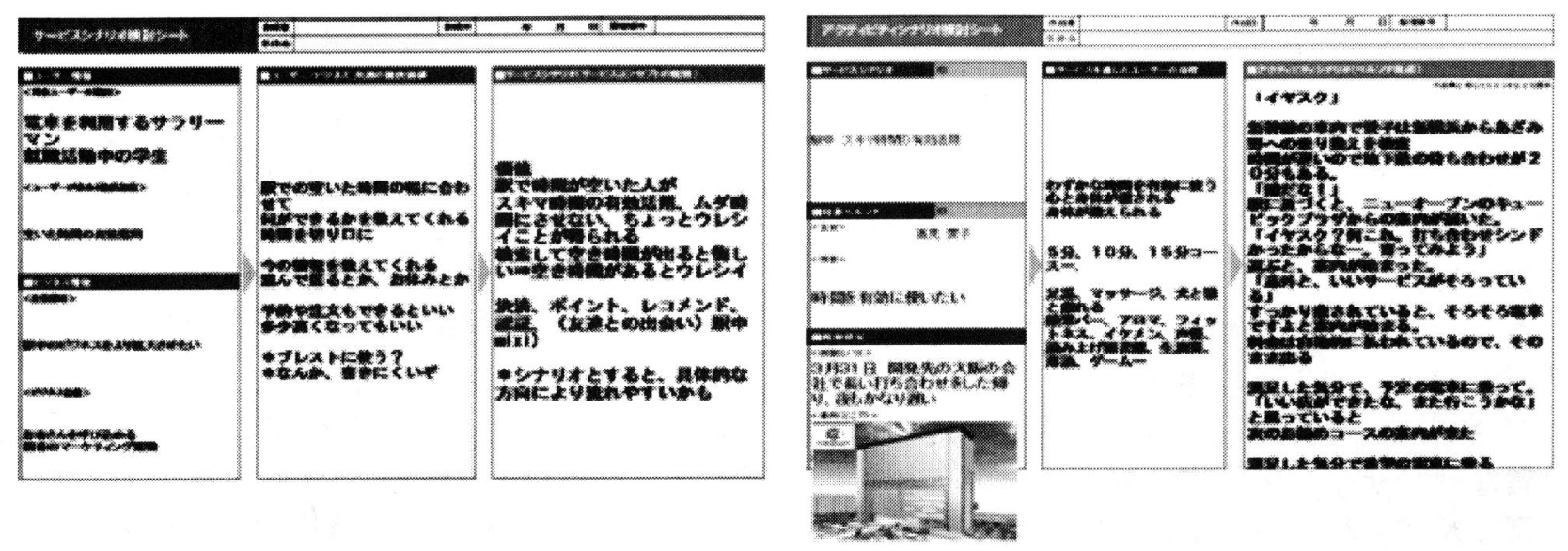

インタラタションジリオ阵封シート

\section{大阪て打ち合わせをした带りの新輖線}

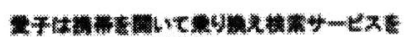

*-

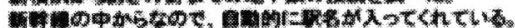

4⿻

(204t, (x)

(a)

-

Clastrt

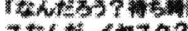

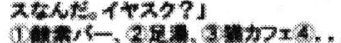

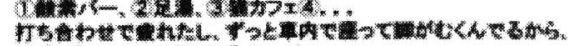

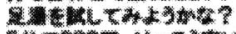

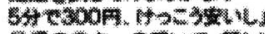

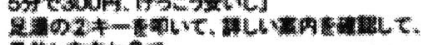

Thutere?

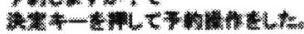

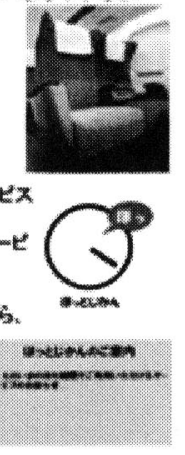

\section{新横浜で降りてイヤスクまで}
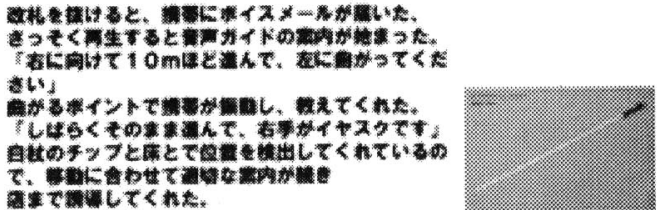

\section{イヤスク内}

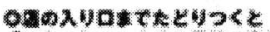

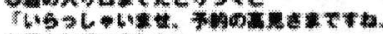

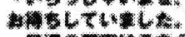
*in

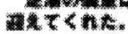

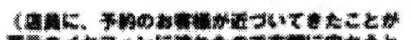

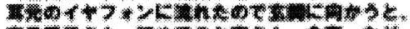

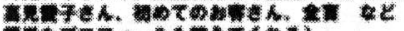

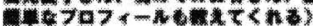

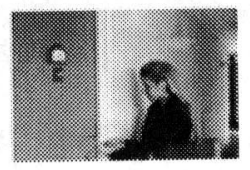

\section{個害内}

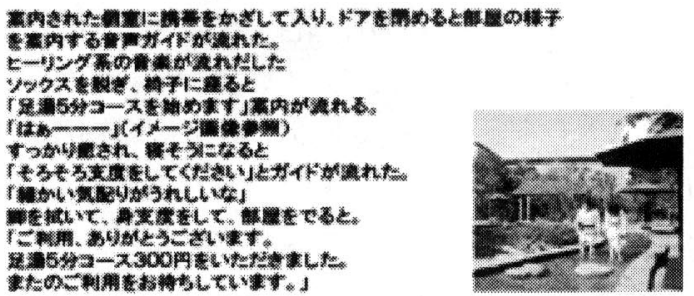

\section{地下鉄内}

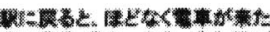

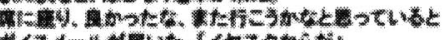

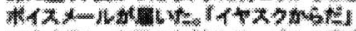

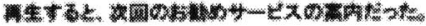

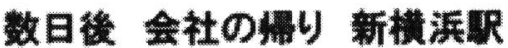

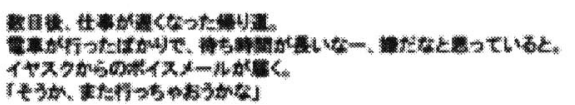

